\title{
Effects of Moringa oleifera and Garcinia kola with or without Grits on Haematological and Serum Biochemical Parameters of Broiler Chickens
}

\author{
Adejola Y.A ${ }^{1 *}$, Sobayo R.A ${ }^{2}$, Muhammad S.B ${ }^{2}$, Ayoola A.A ${ }^{3}$ and Jinadu K.B ${ }^{4}$ \\ ${ }^{\prime}$ Department of Animal Production and Technology, Federal College of Agriculture, P.M.B 5029, Moor Plantation, Ibadan, Oyo State, Nigeria \\ ${ }^{2}$ Department of Animal Nutrition, Federal University of Agriculture Abeokuta, Ogun State, Nigeria \\ ${ }^{3}$ Department of Animal Production and Health, Federal University of Agriculture Abeokuta, Ogun State, Nigeria \\ ${ }^{4}$ Department of Animal Production and Technology, Federal College of Animal Health and Production Technology, P.M.B 5029, Moor \\ Plantation, Ibadan, Oyo State, Nigeria \\ *Corresponding author's E-mail: adejolayusuf@yahoo.com ; ORCID: 0000-0003-1285-759X
}

Received: 14 Oct. 2019

Accepted: 20 Nov. 2019

\begin{abstract}
The use of antibiotics as growth promoters in food animals has been banned due to the residual effects on final consumers which could lead to human health issues. The aim of the present study was to investigate the effects of two herbal feed additives with or without grits on hematological and serum biochemical parameters of broiler chickens. One hundred and forty-four, one-day-old, Cobb 500 broiler chicks were randomly assigned into six treatments (24 birds per treatment) with three replicates (eight bird per replicate). Six dietary treatments were formulated with the inclusion of Moringa oleifera Leaf Meal (MOLM), Garcinia kola Seed Meal (GKSM) and grits. The experimental rations contained diet without MOLM, GKSM and grits which served as treatment 1 (control), diet with MOLM at $1000 \mathrm{ppm}$ (treatment 2), diet with GKSM at 1000ppm (treatment 3), diet with grits at 1000ppm (treatment 4), diet with MOLM at $1000 \mathrm{ppm}+$ grits at $1000 \mathrm{ppm}$ (treatment 5) and diet with GKSM at 1000ppm + grits at 1000ppm (treatment 6). Blood samples were collected on 28 and 56 days of age for hematological and biochemical analysis. Data were subjected to analysis of variance in a completely randomized design. At the starter phase, red blood cells $\left(1.15 \times 10^{12} \mathrm{~L}\right)$ and white blood cells were significantly lowest in birds of first treatment. The birds that received treatment 6 , had the highest glucose $(131.50 \mathrm{~g} / \mathrm{dl})$ and high-density lipoprotein level $(58.50 \mathrm{mg} / \mathrm{dl})$. At the finisher phase, the lowest white blood cell count $\left(10.95 \times 10^{9} / \mathrm{L}\right)$ and lymphocytes $(60 \%)$ were recorded in treatment 6 . Birds in treatment 3 indicated the lowest urea $(2.05 \mathrm{mg} / \mathrm{dl})$ and triglyceride $(94.50 \mathrm{mg} / \mathrm{dl})$. It can be concluded that diet supplemented with GKSM at $1000 \mathrm{ppm}$, increased high-density lipoprotein, and reduced triglyceride and low-density lipoprotein levels in serum of broiler chickens.
\end{abstract}

Key words: Blood parameters, Feed additive, Garcinia Kola, Grit, Moringa oleifera

\section{INTRODUCTION}

Feed additives used in poultry feed improve nutritive value, boost growth performance and feed conversion efficiency and lead to greater liveability and lower mortality in poultry. In the past, growth-promoting antibiotics were administered as feed additives and were associated with residues in the meat and eggs consumed by human, thus the usage of these agents banned or limited in many countries (Diarra et al., 2011; Gadde et al., 2017). Therefore, there is a need to develop new feed additives for replacing antibiotics because growth promoters and performance enhancers are of great importance to the poultry industry (Suresh et al., 2018).

Nowadays, veterinarians have turned attention towards alternative sources from natural ingredients such as herbs or phytogenic plants (phytobiotics) to replace antibiotics. There are reports on the beneficial effects of herbs used as feed supplements or medication in chickens (Ogbe et al., 2009). Certain bioactive chemicals in phytobiotics and herbs are responsible for their therapeutic benefits (Guo et al., 2003; Ogbe et al., 2009). Phytogenic plants generally contain chemical compounds such as saponins, tannins, oxalates, phytates, trypsin inhibitors, and cyanogenic glycosides which are known as secondary metabolites (Soetan and Oyewole, 2009). Secondary metabolites have high amounts of essential nutrients, vitamins, minerals, fatty acids, and fibers (Gafar and Itodo, 2011), therefore apply in nutrition and as pharmacologically-active agents (Soetan and Oyewole, 2009). Previous studies on herbal formulations as feed additives represent promising results in terms of weight 
gain, feed efficiency, lowered mortality and increased liveability in poultry (Jahan et al., 2008).

It is reported that Moringa oleifera, known as the miracle tree, has many medicinal properties and antioxidant activity (Matthew et al., 2001; Ogbunugafor et al., 2011) and could be used as a substitute for conventional feedstuffs as it is a good source of vitamins and amino acids (Sarwart et al., 2002; Olugbemi et al., 2010). It is declared that $M$. oleifera promotes immune systems (Olugbemi et al., 2010). It has been reported that M.oleifera extract has antibacterial properties, thus has the potential to be investigated as a phytotherapeutic agent to combat the infectious organisms (Patel, 2011).

Garcinia kola or bitter kola, also known as African wonder nut, is used as food and herbal medicine (Adesanya et al., 2007). It contains phenolic compounds that possess anti-inflammatory, anti-microbial, antidiabetic and antiviral properties (Adedeji et al., 2006). The presence of biflavonoids and xanthones that act as potent antioxidants, in $G$. kola seeds have been confirmed (Farombi et al., 2002; Oluyemi et al., 2007). Husain et al. (1982) reported antimicrobial activity of G. kola is due to kolanone whereas Iwu (1990) made the same observation with $G$. kola flavanone.

Grits are hard bits of stones, sand and small particles which birds used to enhance mechanical digestion by abrasion in the gizzard (Atteh, 2003). Grits can be classified into soluble fed and insoluble grits. Examples of soluble grits are limestone and oyster shells, which are easily dissolved in the gizzard, they also serve as a source of Calcium. The insoluble grits including silica, mica, and sand are non-digestible and are retained in the gizzard (Adeniji and Oyeleke, 2008). In addition, Atteh (2003) reported that grit improved feed utilization in the birds and average feed intake. To aid the gizzard, picking up a few stones as scavenging for feed is a natural behavior in chickens. These stones facilitate the mechanical digestion of materials that the chicken picks up (Salverson, 1996).

Therefore, the present study aimed to assess the effects of G.kola and M.oleifera as feed additives with or without sand grits on hematological and serum biochemical indices in broiler chickens.

\section{MATERIALS AND METHODS}

\section{Study area}

The present study was carried out in the poultry unit of Directorate of University Farms, Federal University of Agriculture Abeokuta, Nigeria. The area lies in the tropical rain forest vegetation zone. It is located $76 \mathrm{~m}$ above sea level with an average temperature of $34.7^{\circ} \mathrm{C}$ and a relative humidity of $82 \%$.

\section{Ethical approval}

The present study was approved by the ethics and research committee of the Department of Animal Nutrition, Federal University of Agriculture Abeokuta, Ogun State, Nigeria.

\section{Sourcing and processing of test ingredients}

The M. oleifera leaves were obtained from an established Moringa plot in Abeokuta, Ogun State, Nigeria. The $G$ kola seeds were purchased from the Lafenwa market in Abeokuta, Ogun State and the sand grits of around $2 \mathrm{~mm}$ size were obtained from a beach in Ikorodu, Lagos State, Nigeria. Moringa leaves were washed with clean water and dried under shade and then powdered. The M. oleifera Leaf Meal (MOLM) stored in the dark in airtight plastic bags at ambient temperature.

The G. kola seeds were sun-dried and ground using hammer mill and referred to as G. kola Seed Meal (GKSM). The sand grits were sun-dried. All the test ingredients were stored in sacs until needed.

\section{Experimental diets}

Six experimental diets were formulated with the inclusion of herbal feed additives and grits as follows: basal diet (control; diet without herbal feed additives and sand grit; basal diet + MOLM (1000 ppm); basal diet + GKSM (1000 ppm); basal diet + grit (1000 ppm); basal diet + MOLM (1000 ppm) + grit (1000 ppm) and basal diet + GKSM (1000 ppm) + grit (1000 ppm). The starter and finisher diets were formulated as indicated in tables 1 and 2 .

\section{Study design}

A total of 144 one-day-old, unsexed broiler chickens (Cobb 500) were purchased from a commercial hatchery (Zartech Hatchery, Ibadan, Nigeria). On arrival, all chickens were individually weighed and identified (using wing-tags). The birds were randomly divided into six treatment groups with three replicates ( 8 birds per replicate) in each group. Chickens were raised at $33 \pm 1{ }^{\circ} \mathrm{C}$ during the first and second weeks. The temperature was then reduced by $2{ }^{\circ} \mathrm{C}$ every week. Water and feed were provided ad libitum. All birds were reared on a deep litter in an open-sided house and kept under similar management conditions. The chicks were vaccinated against Newcastle disease and infectious bronchitis (LaSota strain and H120 strain at day 7 and 14 via 
drinking water, respectively). Antibiotics were administered as therapeutic agents during the experiment. The study lasted for eight weeks.

\section{Hematological and biochemical analysis}

Blood samples were taken from the jugular vein of two chicks in each replicate on 28 and 56 days of age. The samples were transferred into Eppendorf tubes containing ethylenediaminetetraacetic acid (EDTA), as an anticoagulant to measure hematological parameters including Hemoglobin (Hb), Red Blood Cell (RBC), packed cell volume, White Blood Cells (WBC), and lymphocytes. In addition, for serum separation, blood samples were collected in non-EDTA tubes and allowed to clot for one hour at room temperature, and then centrifuged at 3,000 rpm for $20 \mathrm{~min}$. Collected sera were stored in a deep freezer at $-20^{\circ} \mathrm{C}$ until chemically analyzed. At the time of analysis, the samples were thawed and analyzed for total protein, albumin, glucose, total cholesterol, urea, Low-Density Lipoprotein (LDL), HighDensity Lipoprotein (HDL), Very Low-Density Lipoprotein (VLDL), triglyceride, Aspartate Transaminase (AST) and Alanine Transaminase (ALT).

\section{Statistical analysis}

All data were analyzed using one-way analysis of variance (ANOVA) and the means were compared using Duncan's multiple range test when ANOVA analysis was significant. Data analysis was performed using SPSS 16.0 (SPSS Inc., USA). A p-value of 0.05 or less was considered significant.

Table 1. Composition of experimental diets for Cobb 500 broiler chickens aged 0-4 weeks

\begin{tabular}{|c|c|c|c|c|c|c|}
\hline Ingredients (\%) & $\begin{array}{l}\text { Basal diet } \\
\text { (Control) }\end{array}$ & MOLM & GKSM & Grits & $\begin{array}{c}\text { MOLM + } \\
\text { Grits }\end{array}$ & $\begin{array}{c}\text { GKSM + } \\
\text { Grits }\end{array}$ \\
\hline Maize & 50.00 & 50.00 & 50.00 & 50.00 & 50.00 & 50.00 \\
\hline Wheat offal & 8.00 & 8.00 & 8.00 & 8.00 & 8.00 & 8.00 \\
\hline Soybean meal & 22.00 & 22.00 & 22.00 & 22.00 & 22.00 & 22.00 \\
\hline Groundnut cake & 10.30 & 10.30 & 10.30 & 10.30 & 10.30 & 10.30 \\
\hline Palm Kernel Cake & 2.00 & 2.00 & 2.00 & 2.00 & 2.00 & 2.00 \\
\hline Fish meal & 3.00 & 3.00 & 3.00 & 3.00 & 3.00 & 3.00 \\
\hline Bone meal & 2.00 & 2.00 & 2.00 & 2.00 & 2.00 & 2.00 \\
\hline Oyster shell & 2.00 & 2.00 & 2.00 & 2.00 & 2.00 & 2.00 \\
\hline Lysine & 0.10 & 0.10 & 0.10 & 0.10 & 0.10 & 0.10 \\
\hline Methionine & 0.10 & 0.10 & 0.10 & 0.10 & 0.10 & 0.10 \\
\hline Salt & 0.25 & 0.25 & 0.25 & 0.25 & 0.25 & 0.25 \\
\hline Vitamin \& Mineral Premix* & 0.25 & 0.25 & 0.25 & 0.25 & 0.25 & 0.25 \\
\hline MOLM & - & + & - & - & + & - \\
\hline GKSM & - & - & + & - & - & + \\
\hline Grits & - & - & - & + & + & + \\
\hline Total & 100 & 100 & 100 & 100 & 100 & 100 \\
\hline
\end{tabular}

Calculated Chemical Composition

\begin{tabular}{|c|c|c|c|c|c|c|}
\hline Metabolizable energy (Kcal/Kg) & 2835.13 & 2835.13 & 2835.13 & 2835.13 & 2835.13 & 2835.13 \\
\hline Crude protein $(\%)$ & 22.44 & 22.44 & 22.44 & 22.44 & 22.44 & 22.44 \\
\hline Crude fibre $(\%)$ & 4.03 & 4.03 & 4.03 & 4.03 & 4.03 & 4.03 \\
\hline Fat $(\%)$ & 4.29 & 4.29 & 4.29 & 4.29 & 4.29 & 4.29 \\
\hline $\mathrm{Ca}(\%)$ & 1.66 & 1.66 & 1.66 & 1.66 & 1.66 & 1.66 \\
\hline $\mathrm{P}(\%)$ & 0.82 & 0.82 & 0.82 & 0.82 & 0.82 & 0.82 \\
\hline
\end{tabular}

*Premix to provide the following: Vitamin A 12,000,000I.U; Vitamin D3 3,000.000I.U; Vitamin E 30,000mg; Vitamin K 2,500mg; folic acid 1,000mg; Niacin 40, 000mg; Cal Pan 10,000mg; Vitamin B12 20mg; Vitamin B12,000mg; Vitamin B6 3,500mg; Biotin 80mg; Antioxidant 125,000mg; Cobalt 250mg; Selenium 250mg; Iodine1,200mg; Iron 40,000mg; Manganese 70,000mg; Copper 8,000mg; Zinc 60,000mg; Chlorine 200,000mg. +: 1000 ppm, MOLM: Moringa oleifera Leaf Meal, GKSM: Garcinia kola Seed Meal 
Table 2. Composition of experimental diets for Cobb 500 broiler chickens aged 4-8 weeks

\begin{tabular}{|c|c|c|c|c|c|c|}
\hline Ingredients (\%) & $\begin{array}{l}\text { Basal diet } \\
\text { (Control) }\end{array}$ & MOLM & GKSM & Grits & $\begin{array}{c}\text { MOLM + } \\
\text { Grits }\end{array}$ & $\begin{array}{c}\text { GKSM + } \\
\text { Grits }\end{array}$ \\
\hline Maize & 54.00 & 54.00 & 54.00 & 54.00 & 54.00 & 54.00 \\
\hline Wheat offal & 10.00 & 10.00 & 10.00 & 10.00 & 10.00 & 10.00 \\
\hline Soybean Meal & 16.00 & 16.00 & 16.00 & 16.00 & 16.00 & 16.00 \\
\hline Palm kernel cake & 3.00 & 3.00 & 3.00 & 3.00 & 3.00 & 3.00 \\
\hline Groundnut cake & 9.30 & 9.30 & 9.30 & 9.30 & 9.30 & 9.30 \\
\hline Fish meal & 3.00 & 3.00 & 3.00 & 3.00 & 3.00 & 3.00 \\
\hline Bone meal & 2.00 & 2.00 & 2.00 & 2.00 & 2.00 & 2.00 \\
\hline Oyster shell & 2.00 & 2.00 & 2.00 & 2.00 & 2.00 & 2.00 \\
\hline Lysine & 0.10 & 0.10 & 0.10 & 0.10 & 0.10 & 0.10 \\
\hline Methionine & 0.10 & 0.10 & 0.10 & 0.10 & 0.10 & 0.10 \\
\hline Salt & 0.25 & 0.25 & 0.25 & 0.25 & 0.25 & 0.25 \\
\hline Vitamin \& Minreal Premix* & 0.25 & 0.25 & 0.25 & 0.25 & 0.25 & 0.25 \\
\hline MOLM & - & + & - & - & + & - \\
\hline GKSM & - & - & + & - & - & + \\
\hline Grits & - & - & - & + & + & + \\
\hline Total & 100 & 100 & 100 & 100 & 100 & 100 \\
\hline \multicolumn{7}{|c|}{ Calculated Chemical Composition } \\
\hline Metabolizable energy (Kcal/Kg) & 2875.33 & 2875.33 & 2875.33 & 2875.33 & 2875.33 & 2875.33 \\
\hline Crude Protein $(\%)$ & 20.24 & 20.24 & 20.24 & 20.24 & 20.24 & 20.24 \\
\hline Crude Fiber (\%) & 3.98 & 3.98 & 3.98 & 3.98 & 3.98 & 3.98 \\
\hline Fat $(\%)$ & 4.27 & 4.27 & 4.27 & 4.27 & 4.27 & 4.27 \\
\hline $\mathrm{Ca}(\%)$ & 1.65 & 1.65 & 1.65 & 1.65 & 1.65 & 1.65 \\
\hline $\mathrm{P}(\%)$ & 0.82 & 0.82 & 0.82 & 0.82 & 0.82 & 0.82 \\
\hline
\end{tabular}

*Premix to provide the following: Vitamin A 12,000,000I.U; Vitamin D3 3,000.000I.U; Vitamin E 30,000mg;Vitamin K 2,500mg; folic acid 1,000mg; Niacin 40, 000mg; Cal Pan 10,000mg; Vitamin B12 20mg; Vitamin B12,000mg; Vitamin B6 3,500mg; Biotin 80mg; Antioxidant 125,000mg; Cobalt 250mg; Selenium 250mg; Iodine1,200mg; Iron 40,000mg; Manganese 70,000mg; Copper 8,000mg; Zinc 60,000mg; Chlorine 200,000mg. +: 1000ppm, MOLM: Moringa oleifera Leaf Meal, GKSM: Garcinia kola Seed Meal

\section{RESULTS}

Effects of experimental diets on the hematological and serum biochemical indices during the starter phase (0-4 weeks)

Table 3 shows the main effects of herbal feed additives and grits on hematological and serum biochemical indices of the birds in $4^{\text {th }}$ week. The $\mathrm{Hb}$, $\mathrm{RBC}$, and WBC were significantly influenced by herbal feed additives and grits $(p<0.05)$. The birds fed on the control diet and GKSM + grits recorded significantly lower $\mathrm{Hb}$ values $(7.15$ and $7.75 \mathrm{~g} / \mathrm{dl}$; respectively) $(\mathrm{p}<0.05)$ while other treatment groups had comparable values. The highest and lowest value for RBC were recorded in birds fed on GKSM and control diets; respectively $(\mathrm{p}<0.05)$. The birds fed basal diet + grits recorded significantly higher value $\left(13.6 \times 10^{9} / \mathrm{L}\right)$ for $\mathrm{WBC}(\mathrm{p}<0.05)$, followed by groups fed GKSM while others had comparable lower values. Other parameters measured were not significantly influenced by herbal feed additives and grits. The glucose, urea, and HDL were significantly affected by herbal feed additives and grits. The birds fed grits indicated significantly the highest glucose value $(\mathrm{p}<0.05)$ while those fed MOLM had the lowest value. The birds fed on control diet recorded significantly the highest urea value (2.35 $\mathrm{mg} / \mathrm{dl} ; \mathrm{p}<0.05)$ whereas other values were comparable across the treatments. The birds fed MOLM + grits and GKSM + grits recorded similar HDL levels $(58.50 \mathrm{mg} / \mathrm{dl})$, which were not significantly higher than other treatment groups.

Effects of experimental diets on the hematological and serum biochemical indices during the finisher phase (4-8 weeks)

Table 4 displays the effects of herbal feed additives and grits on hematological and serum parameters of broiler chickens in $8^{\text {th }}$ week. There were significant differences in most of the hematological parameters measured. The values of WBC were significantly lower $(\mathrm{p}<0.05)$ in birds fed MOLM + grits and GKSM + grits 
$\left(10.65 \times 10^{9} / \mathrm{L}\right.$ and $10.95 \times 10^{9} / \mathrm{L}$; respectively) compared to control group which had the highest value of $14.05 \times 10^{9} / \mathrm{L}$. Groups fed grit and GKSM + grits had heterophils values of 39.50 and $40.00 \%$, respectively, and were significantly higher than other treatment groups $(\mathrm{p}<0.05)$. The lymphocytes in the blood of the birds fed on MOLM + grits and GKSM + grits were significantly lower compared to the control birds $(\mathrm{p}<0.05)$. Monocyte value $(1.00 \%)$ was highest in the control group while the least value (0.0001) was recorded in other groups except group fed MOLM + grit with a monocyte value of $0.5 \%$. The MCV value in MOLM treatment $(182 \mathrm{fL})$ was significantly higher than the other groups. Other parameters measured were not significantly influenced by dietary treatments.

Feed additives and grits supplementation influenced some serum parameters including globulin, AST, urea, triglyceride, LDL, and VLDL. The lowest and highest globulin levels were achieved in the birds fed on control diets and GKSM; respectively $(\mathrm{p}<0.05)$. The AST concentration in birds fed on GKSM was significantly higher $(62.50 \mathrm{U} / \mathrm{L} ; \mathrm{p}<0.05)$ than those fed MOLM + grits which had the lowest value of $56.00 \mathrm{U} / \mathrm{L}$. The highest urea value was observed in birds fed MOLM + grits $(\mathrm{p}<0.05)$ while those fed control, MOLM, and GKSM had similar values. The lowest triglyceride value was achieved in birds fed GSKM $(\mathrm{p}<0.05)$ while birds in MOLM, grits, and GKSM + grits treatments had similar values. The LDL level in MOLM + grits treatment was significantly higher compared to GSKM + grits treatment $(\mathrm{p}<0.05)$. The lowest level of VLDL was achieved in birds fed MOLM $(\mathrm{p}<0.05)$ while those fed GKSM, grits and GSKM + grits had similar values.

\section{DISCUSSION}

Blood parameters are considered valuable indicators for health status (Rehman et al., 2017). The values of $\mathrm{Hb}$, $\mathrm{RBC}$, and WBC obtained in the present study were within the normal ranges reported by Morton et al. (1993). The numerical differences observed in the $\mathrm{Hb}$ and $\mathrm{RBC}$ levels in birds fed herbal feed additives solely or with grits suggests that the diets were better utilized and assimilated into the bloodstream for use by the birds. Hematological studies in birds demonstrated that RBC and other parameters such as $\mathrm{Hb}$ vary among bird species and are affected by diet contents, (Odunsi et al., 2002) physiological and environmental conditions (Alodan and Mashaly, 1999). Olugbemi et al. (2010) reported that hemoglobin was not significantly affected when broiler chickens were fed with Moringa oleifera.

The glucose concentrations in this study were within the normal range reported by Mitruka and Rawsley (1977). Glucose is one of the metabolites which represent the energy status of the animal. Normal glucose levels in birds indicate adequate synthesis in the liver from propionate, a major glucose precursor (Houtert, 1993). The results are in line with the findings of Udenze et al. (2012b) who reported that $G$. kola powder reduces glucose concentrations in diabetic animals and normalize glycemia at the highest dose.

In the present study, the high HDL level at starter phase as well as lower values of triglycerides, LDL, and cholesterol at the finisher phase indicated that the diets containing G. kola have good lipid-lowering agents, which is associated with a reduced risk of cardiovascular diseases (Ouyang et al., 2016). The reduction of triglycerides and LDL could be attributed to the inhibitory effect of G. kola seed on the accumulation of lipid droplets in adipocytes (Noboru, 2001). Ali et al. (2007) found that adding thyme to hen's ration significantly decreased plasma HDL, total cholesterol, triglycerides, and total lipids. Contrarily, Bolukbasi et al. (2006) reported that dietary thyme oil increases plasma concentration of triglycerides, LDLcholesterol and HDL-cholesterol in broiler chickens.

\section{CONCLUSION}

It is concluded that diet supplemented with GKSM at $1000 \mathrm{ppm}$ increases high-density lipoprotein, reduces triglyceride and low-density lipoprotein levels in serum of broiler chickens.

\section{DECLARATIONS}

\section{Acknowledgments}

This study was supported by the Animal Nutrition Laboratory of the Department of Animal Nutrition, Federal University of Agriculture Abeokuta, Ogun State, Nigeria.

\section{Competing interests}

The authors have declared that no competing interest exists.

\section{Authors' contributions}

Adejola YA designed the analysis, collected the data and wrote the manuscript. Sobayo RA supervised and designed the analysis. Muhammed SB contributed analysis tool and performed the analysis. Ayoola AA collected the data and performed the analysis. Jinadu KB wrote the paper. 


\section{REFERENCES}

Adedeji OS, Farimi GO, Ameen SA and Olayemi JB (2006). Effects of bitter kola (Garcinia kola) as growth promotes in broiler chicks from day old to four weeks old. Journal of Animal and Veterinary Advances, 5: 191-193. Available at:https://www.google.com/amp/medwelljournals.com/abst ract/amp.php\%3fdoi=javaa.2006.191.193

Adeniji AA and Oyeleke MM (2008). Effects of dietary grit fed on the utilization of rumen content by pullet chicks. Journal of Applied Science Research, 4: 1257-1260. Available http://www.aensiweb.com/old/jasr/jasr/2008/12571260.pdf

Adesanya OA, Oluyemi KA, Olusori DA, Omotuyi, IO, Okwuonu CU, Ukwenya OV and Adesanya RA (2007). Micromorphometric and stereological effects of ethanolic extracts of Garcinia cambogia seeds on the testes and epididymides of adult Wistar rats. International Journal of Alternative Medicine, 5:1. Available at: http://ispub.com/IJAM/5/1/5126

Ali MN, Hassan MS and El Ghany FA (2007). Effect of strain, type of natural antioxidant and sulphate ion on productive, physiological and hatching performance of native laying hens. International Journal of Poultry Science, 6: 539-554. Available at:

DOI: https://doi.org/10.3923/ijps.2007.539.554

Alodan MA and Mashaly MM (1999). Effect of induced moulting in laying hens on production and immune parameters. Poultry Science 78, 171-177. DOI: Available at: https://doi.org/10.1093/ps/78.2.171

Atteh JO (2003). Principle and practices of livestock feed manufacturing, 3rd Edition. Adlek, Ilorin, pp. 45- 46.

Bolukbası SC, Erhan MK and Özkan A (2006). Effect of dietary thyme oil and vitamin $\mathrm{E}$ on growth, lipid oxidation, meat fatty acid composition and serum lipoproteins of broilers. South African Journal of Animal Science, 36 (3): 189-196. Available at: https://www.semanticscholar.org/paper/Effect-of-dietarythyme-oil-and-vitamin-E-on-lipid-BolukbasiErhan/ed1b2304bbfcda68b23bf7cab71f143e06b9beb7

Campbell JR, Kencaly MD and Campbell KI (2003). Anatomy and Physiology of farm animals: In Animal Science. The biology care and Production of domestic animals, 4th Edition. McGraw Hill Company Inc., New York, pp. 70

Diarra SS, Kwari ID, Girgiri YA, Saleh B and Igwebuike JU (2011). The use of sorrel (Hibiscuss sabdariffa) seed as a feed ingredient for poultry. A review. Research Opinions in Animal and Veterinary Science, 1: 573-577. Available at: http://www.roavs.com/archive/vol-1-issue-9-2011.htm

Farombi EO, Adepoju SE, Ola-Davies OE and Emerola GO (2005). Chemo prevention of aflatoxin Bi-included genotoxicity and hepatic oxidative damage in rats by klaviron, a natural bioflavonoid of Garcinia kola seeds. European Journal of Cancer Prevention, 14 (3):207-214. DOI: https://doi.org/10.1097/00008469-200506000-00003

Gadde U, Kim WH, Oh ST and Lillehoj HS (2017). Alternatives to antibiotics for maximizing growth performance and feed efficiency in poultry: a review. Animal Health Research
Reviews, $\quad 18: \quad 26-45 . \quad$ DOI: https://doi.org/10.1017/s1466252316000207

Gafar MK and Itodo AU (2011). Proximate and mineral composition of hairy indigo leaves. In Electronic Journal of Environmental, Agricultural and Food Chemistry, 10 (3): 2007-2018.

Guo FC, Sacelkoul HFJ, Kwakkel RP, Williams BA and Verstegen MWA (2003). Immunoactive, medicinal properties of mushroom and herb polysaccharides and their potential use in chicken diets. World's Poultry Science Journal, 59(4):427-440. DOI: https://doi.org/10.1079/wps20030026

Houtert MF (1993). The production and metabolism of volatile fatty acids by ruminants fed roughages: A review. Animal Feed Science and Technology, 43: 189-225. DOI: https://doi.org/10.1016/0377-8401(93)90078-X

Husain RA, Cwegby AG, Parimoo P and Waterman PG (1982). A novel Polyisopremylated benzophenone with antibacterial properties from fruit of Garcinia kola. Plant Medicine, 44:78-81.

Iwu MM, Igboko OA and Tempesta MS (1990). Biflavanoids constituents of Garcinia kola root. Fitoterapia, 61 (2): 178.

Jahan ZA, Ahsan UH, Muhammad Y, Tanveer A and Sarzamin K (2008). Evaluation of different medicinal plants as growth promoters for broiler chicks. Sarhad Journal of Agriculture, 24: 323-329. Available at: http://www.aup.edu.pk/SJA-search.php?volume_issue $=24 \% 7 \mathrm{C} 2 \% 7 \mathrm{C} 2008$

Matthew T, Matthew Z, Taji S A and Zachariah S (2001). A review of viricidal ayurvedic herbs of India for poultry diseases. Journal of American Holistic Veterinary Medicine Association, 20 (1): 17-20.

Mitruka BM and Rawnsley HM (1977). Clinical biochemical and hematological reference values in normal experimental animals. Masson Publicity Corporation, New York, pp. 102-117. Available at: https://www.cabdirect.org/cabdirect/mobile/abstract/19782 202260

Morton DB, Abbot D, Barclay R, Close BS, Ewbank R, Gask D, Heath M, Mattic S, Poole T and Seamer J (1993). Removal of blood from laboratory mammals and birds. First report of the BVA/FRAME/RSPCA/UFAW Joint working group on refinement. Laboratory Animals, 27: 1-22

Odunsi AA, Ogunleke, MO, Alagbe OS and Ajani TO (2002). Effect of feeding Gliricidia sepium leaf meal on the performance and egg quality of layers. International Journal of Poultry Science, 1: 26-29. DOI: https://doi.org/10.3923/ijps.2002.26.28

Ogbe AO, Atawodi SE, Abdu PA, Sannusi A and Itodo AE (2009). Changes in weight, faecal oocyst count and packed cell volume of Eimeria tenella-infected broilers treated with a wild mushroom (Ganoderma lucidum) aqueous extract. Journal of the South African Veterinary Association, $\quad 80$ : $2 . \quad$ DOI: https://doi.org/10.4102/jsava.v80i2.179

Olugbemi TS, Mutayoba SK and Lekule FP (2010). Effect of Moringa (Moringa oleifera) Inclusion in Cassava based diets to broiler chickens. In: International Journal of Poultry Science, $\quad$ 9: 363-367. DOI:https://doi.org/10.3923/ijps.2010.363.367 
Oluyemi KA, Omotuyi IO, Jimoh OR, Adesanya OA, Saalu CL and Josiah SJ (2007). Erythropoietic and Anti-obesity effects of Garcinia cambogia (Bitter kola) in Wistar Rats. Biotechnology Application in Biochemistry, 46:69-72. DOI: https://doi.org/10.1042/ba20060105

Ouyang KH, Xu MS, Jiang Y and Wang WJ (2016). Effects of alfalfa flavonoids on broiler performance, meat quality, and gene expression. Canadian Journal of Animal Science, 96:332-341. DOI: https://doi.org/10.1139/cjas-2015-0132

Patel NK (2011). Phytotherapeutic Investigation of Major Herbal Steroids to explore their potentials as an alternative to synthetic steroids. Ph.D. thesis, Saurashtra University.

Rehman MS, Mahmud A, Mehmood S, Pasha TN, Hussain J and Khan MT (2017). Blood biochemistry and immune response in Aseel chicken under free range, semi-intensive and confinement rearing systems. Poultry Science, 96:226233. DOI: https://doi.org/10.3382/ps/pew278

Salverson CA (1996). Grit feeding in caged layers on Performance, Carcass Composition and Blood Chemistry Changes in Broiler Chickens. Canadian Journal of Animal Science, 71: 939-942.

Sarwatt SV, Kapange SS and Kakengi AMV (2002). The effects on intake, digestibility and growth of goats when sunflower seed cake is replaced with Moringa oleifera leaves in supplements fed with Chloris gayana hay. In: Agroforestry systems, 56: 241-247. DOI: https://doi.org/10.1023/a:1021396629613

Soetan KO and Oyewole OE (2009). The need for adequate processing to reduce the anti-nutritional factors in plants used as human foods and animal feeds, a review. American Journal of Food Science, 3: 223-231. Available at: https://academicjournals.org/journal/AJFS/edition/Septemb er_2009

Suresh G, Das RK, Kaur Brar S, Rouissi T, Avalos Ramirez A, Chorfi Y and Godbout S (2018). Alternatives to antibiotics in poultry feed: molecular perspectives. Critical Reviews in Microbiology, 44:318-335. DOI: https://doi.org/10.1080/1040841x.2017.1373062

Udenze ECC, Braide VB, Okwesilieze CN, Akuodor GC and Odey MO (2012). The effects of gavage treatment with Garcinia kola seeds on biochemical markers of liver functionality in diabetic rats. Annals of Biological Research, 3 (9): 4601-4608. Available at: https://www.scholarsresearchlibrary.com/archive/abrvolume-3-issue-9-year-2012.html 